\title{
Method for hatching resting eggs from tropical zooplankton: effects of drying or exposing to low temperatures before incubation
}

Método para a eclosão de ovos de resistência do zooplâncton tropical: efeitos da seca ou exposição a baixas temperaturas antes da incubação

Jayme Magalhães Santangelo ${ }^{1}$, Luciana Rabelo Araújoº

Francisco de Assis Esteves ${ }^{2}$, Marina Manca $^{3}$ and Reinaldo Luiz Bozelli

${ }^{1}$ Departamento de Ciências Ambientais, Instituto de Florestas,

Universidade Federal Rural do Rio de Janeiro - UFRRJ,

Rod. BR 465, Km 07, CEP 23890-000, Seropédica, RJ, Brazil e-mail: jaymems@gmail.com

${ }^{2}$ Universidade Federal do Rio de Janeiro - UFRJ,

Av. Carlos Chagas Filho, 373, CP 68020, CEP 21941-902, Rio de Janeiro, RJ, Brazil e-mail: lucy_rabelo@yahoo.com.br; festeves@biologia.ufrj.br; bozelli@biologia.ufrj.br

${ }^{3}$ CNR Institute for the Study of Ecosystems, Largo Tonolli 52, 28922, Verbania (VB), Italy e-mail: m.manca@ise.cnr.it

\begin{abstract}
Aim: In this study we tested the effects of drying or refrigerating $\left(4^{\circ} \mathrm{C}\right)$ cladoceran resting eggs from a tropical aquatic system on the hatching rates and time to hatching, in order to determine what conditions should or should not be applied to break dormancy in tropical cladocerans; Methods: Resting eggs from two cladoceran species were isolated from the sediment of a coastal lagoon and exposed to drying conditions or low temperatures for four months before incubation under control conditions; Results: For Moina micrura, drying as well as refrigerating eggs reduced the proportion of eggs hatched, but refrigeration also reduced the time to hatching. For Diaphanosoma birgei, refrigeration had no effects either in the proportion of eggs hatched or in time to hatching. Drying resting eggs of $D$. birgei resulted in no hatchlings after re-hydration; Conclusions: Our results indicate that the pre-exposure of tropical cladoceran resting eggs to low temperatures might not be necessary to break dormancy. Additionally, cooling might even reduce the hatching rates of some species. We suggest that tropical cladoceran resting eggs might be incubated soon after sampling the sediment or, if a period for breaking dormancy is required, they should be better kept under dark and at room temperature conditions.
\end{abstract}

Keywords: hatching rate, dormancy, resting eggs, Cladocera, tropical zooplankton.

Resumo: Objetivo: Nesse estudo foram testados os efeitos da secagem ou resfriamento $\left(4^{\circ} \mathrm{C}\right)$ dos ovos de resistência de cladóceros de um sistema aquático tropical sobre as taxas de eclosão e o tempo para eclosão, com o objetivo de determinar quais procedimentos devem ou não ser aplicados para quebrar a dormência de cladóceros oriundos de regióes tropicais; Métodos: Os ovos de resistência de duas espécies de cladóceros foram isolados do sedimento de uma lagoa costeira e secados sob temperatura ambiente ou expostos à baixas temperaturas por quatro meses antes da incubação nas condiçôes de controle; Resultados: Para Moina micrura, tanto a secagem quanto o resfriamento reduziram a proporção de ovos eclodidos, mas a pré-exposição à baixa temperatura também reduziu o tempo para a eclosão. Para Diaphanosoma birgei, o resfriamento não teve efeitos na taxa e no tempo para eclosáo. Nenhum dos ovos de $D$. birgei secos eclodiu após a reidratação; Conclusóes: Os resultados indicam que a pré-exposição de ovos de resistência de cladóceros tropicais a baixas temperaturas não deve ser necessária para quebrar a dormência. Além disso, o resfriamento pode até mesmo reduzir a taxa de eclosão de algumas espécies. Sugere-se que os ovos de resistência de cladóceros tropicais podem ser incubados logo após a amostragem do sedimento ou, se um período para quebrar a dormência for necessário, os ovos devem ser mantidos preferencialmente no escuro e em temperatura ambiente.

Palavras-chave: taxa de eclosão, dormência, ovos de resistência, Cladocera, zooplâncton tropical. 


\section{Introduction}

Identifying the composition of egg banks from zooplankton has proved an important tool for biodiversity studies (Vandekerkhove et al., 2005b). In most cases, comparison of active and dormant stages reveals that species composition does not overlap completely (Crispim and Watanabe, 2001; Garcia-Roger et al., 2008). However, when assessing the diversity of zooplankton by hatching resting eggs, a common problem is to find the specific cues to break dormancy and then initiate hatching of all species.

Resting eggs must pass through a mandatory period of dormancy before they can hatch (Stross, 1987). After such period, some environmental cues break dormancy and, when exposed to the ideal conditions, such as appropriate light and temperature (Vandekerkhove et al., 2005a), resting eggs hatch. Several studies have attempted to find the best environmental cues to break dormancy and induce hatching in the laboratory, combining different temperatures and exposure to light (De Meester and De Jager, 1993a; Schwartz and Hebert, 1987; Vandekerkhove et al., 2005a). In spite of variable conditions are combined to stimulate hatching, the break of dormancy is usually achieved by exposing resting eggs to low temperatures $\left(-4^{\circ} \mathrm{C}\right)$ in the dark for three months to one year, simulating (temperate) winter conditions (Caceres and Schwalbach, 2001; Vandekerkhove et al., 2005b).

Several studies have made clear that tropical zooplankton produces resting eggs. Additionally, the number of studies involving the hatching of resting eggs from tropical zooplankton is growing fast (e.g. Pallazo et al., 2008a; Panarelli et al., 2008). Hence, the optimization of techniques to break dormancy and then hatch tropical eggs is required. So far, different mechanisms have been applied. For example, resting eggs from a reservoir and two floodplain lakes in Brazil were refrigerated in the dark before incubation in order to break dormancy (Maia-Barbosa et al., 2003; Pallazo et al., 2008a,b), although such low temperatures are never observed under natural conditions. In contrast, resting eggs from a coastal lagoon were kept only under room temperatures in the dark before exposed to hatching conditions (Santangelo et al., 2010). Other authors studying dry sediments used no specific cues to break dormancy, and incubated resting eggs soon after sediment sampling (Brock et al., 2003; Crispim and Watanabe, 2001; Panarelli et al., 2008).

In this study we describe the hatching rates and the time to hatching of tropical cladoceran resting eggs (Diaphanosoma birgei and Moina micrura) exposed to three conditions before incubation. Resting eggs obtained from lake sediments were allowed to hatch without any prior treatment and after drying or exposing them to low temperatures. We hypothesized that the exposure of tropical cladoceran resting eggs either to low temperatures or to drying conditions reduces the hatching rates and increases the time to hatching. The general aim of this approach was to suggest optimal environmental cues to break dormancy and then stimulate hatching in tropical cladocerans.

\section{Material and Methods}

We used resting eggs from the cladocerans Moina micrura (Kurz, 1874) and Diaphanosoma birgei Korinek, 1981 to test different methods for breaking dormancy. Moina and Diaphanosoma are two of the most common genus in tropical zooplankton (Sarma et al., 2005). All eggs were obtained from wet sediments of Carapebus lagoon (22 $15^{\circ} \mathrm{S}$ and $\left.40^{\circ} 35 \mathrm{~W}^{\prime}\right)$, Rio de Janeiro State, Brazil. Carapebus lagoon has been subject to eutrophication, due to increased nutrient loading from domestic and industrial sewage (Attayde and Bozelli, 1998). The lagoon has an area of $6.5 \mathrm{~km}^{2}$, mean and maximum depth of 2.3 and $4 \mathrm{~m}$, respectively. Secchi depths vary from 0.5 to $1.0 \mathrm{~m}$ (Attayde and Bozelli, 1998), indicating that light never reaches the sediment.

Sediment samples were collected using a core sampler $\left(\varnothing=8 \mathrm{~cm} ; A=50 \mathrm{~cm}^{2}\right)$. Only the top $3 \mathrm{~cm}$ of the sediment core were taken and kept in a single plastic bag in the dark. On the date of sampling, resting eggs of M. micrura and $D$. birgei were isolated from the sediment using the sugar flotation method (Vandekerkhove et al., 2004). Eggs of both species were separated under a stereomicroscope. Ephippium of M. micrura carry one egg. M. micrura resting eggs were not decapsulated before incubation. Resting eggs of $D$. birgei are released without an ephippium. A description of the resting eggs of $M$. micrura and D. birgei is available in Goulden (1968) and Korovchinsky (1992), respectively.

In total, 300 healthy-looking resting eggs of M. micrura and 345 resting eggs of D. birgei were used. For each species, resting eggs were evenly divided between 15 culture cells. Thus, for each treatment, we used five replicates with 20 eggs for M. micrura and five replicates with 23 eggs for D. birgei. Soon after being sorted from the sediments, the eggs were exposed to the three following treatments: 
1) DRY: the resting eggs were dried and kept in the dark for 4 months under room temperatures. To be dried, eggs were placed in low amounts of water, which evaporated within 24 hours under room temperature in the dark.

2) COLD: the resting eggs were kept wet and refrigerated in the dark at $4{ }^{\circ} \mathrm{C}$ for 4 months, to simulate temperate winter temperature. This procedure has been used before to hatch tropical cladoceran resting eggs (MaiaBarbosa et al., 2003; Pallazo et al., 2008b).

3) CONTROL, the resting eggs were allowed to hatch without any pre-treatment, soon after sampling.

After the pre-treatments and in control, eggs were incubated in $2 \mathrm{~mL}$ of filtered (GF/F glass fibre filters) Cabiúnas lagoon water and exposed to $24^{\circ} \mathrm{C}$ and a 12:12 hours light : dark cycle. Filtered water was kept frozen for hatching eggs exposed to DRY and COLD. Hatching was checked every day for 15 days. Medium and culture cells were changed daily. Proportion of hatched eggs and the time to hatching of each species in the different treatments and in the control were compared. An arcsine square root transformation was applied for the proportion of hatched eggs, while time to hatching was $\log _{10}$ transformed before analysis. Because assumptions of parametric tests were not met, we compared $M$. micrura results with a Kruskal-Wallis test followed by Dunn's multiple comparison tests. Data for $D$. birgei were compared with Mann-Whitney $\mathrm{U}$ tests, because no hatchlings were observed under the DRY treatment. A replicate of $M$. micrura eggs under DRY treatment was removed for time to hatching analysis, because no eggs hatched. Statistical analyses were performed using GraphPad Prism 4.0.

\section{Results}

Overall, only $18 \%$ (54) of $M$. micrura and 6\% (20) of $D$. birgei resting eggs hatched. The hatching proportion of $M$. micrura eggs was different in the treatments (Kruskal-Wallis, $\mathrm{P}<0.02$ ). Proportion of hatching was significantly higher in the CONTROL than in the DRY and COLD treatments (Figure 1a). Resting eggs of $D$. birgei hatched in a similar proportion in the CONTROL and in the COLD treatment. Differences were not statistically significant (Mann-Whitney test,
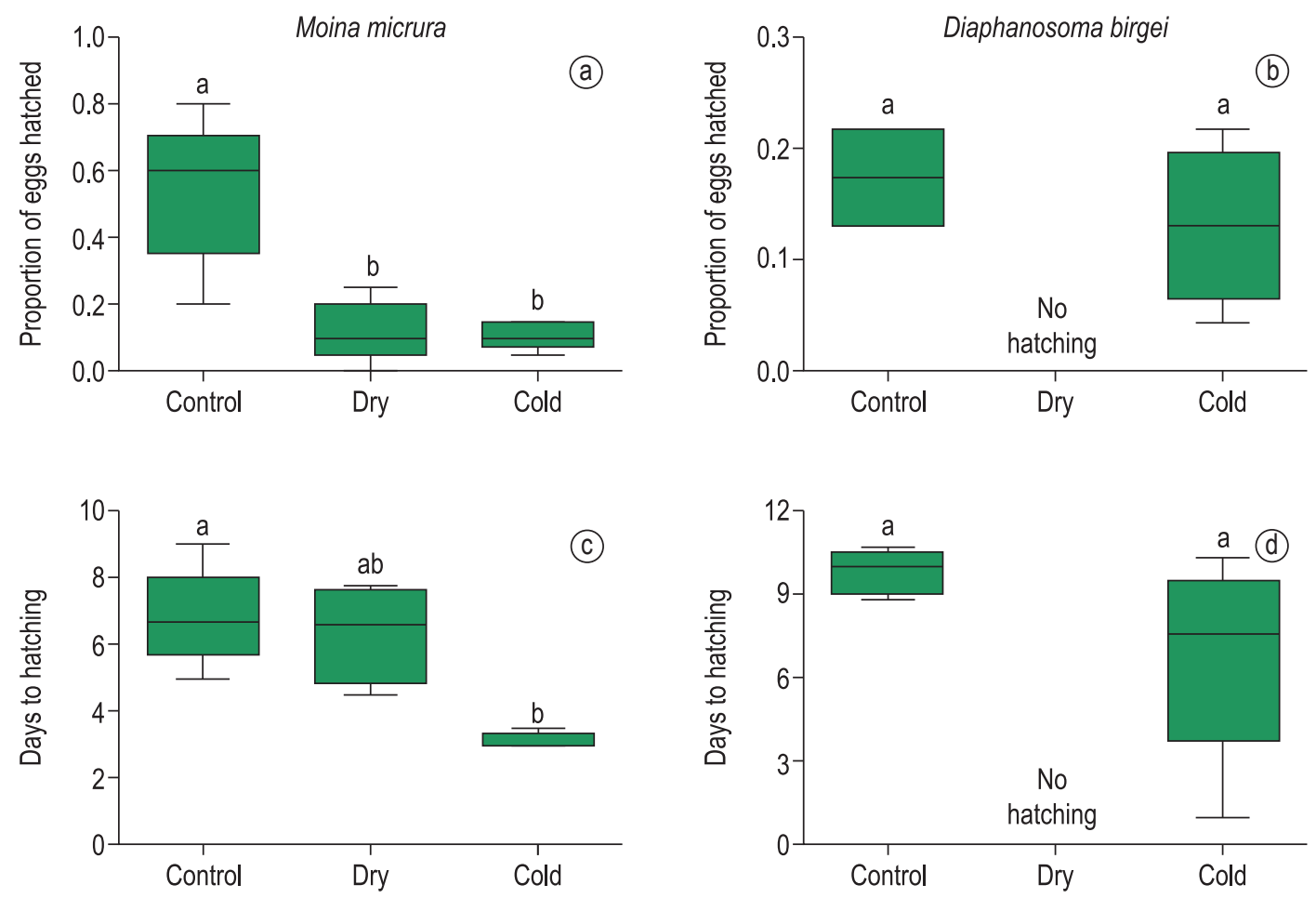

Figure 1. Box and Whisker plots of the hatching responses of Moina micrura and Diaphanosoma birgei resting eggs under the experimental conditions. Internal lines stand for medians, the top and bottom of each box stand for the third and first quartiles, respectively; the whiskers are the lines reaching the smallest and largest values. Different letters above boxes denote significant differences between treatments. See text for further explanations. 
$\mathrm{P}=0.46)$. No hatchlings were recorded in the DRY treatment (Figure 1b).

Time to hatching of $M$. micrura resting eggs was different in the different experimental conditions (Kruskal-Wallis, $\mathrm{P}<0.05$ ). In the CONTROL it was significantly longer than in the COLD treatment. Intermediate intervals were observed in the DRY treatment (Figure 1c). No significant difference in time to hatching (Mann-Whitney test, $\mathrm{P}=0.06)$ of $D$. birgei resting eggs was recorded between the COLD treatment and the CONTROL (Figure 1d).

\section{Discussion}

Here we attempted to determine the best conditions to break dormancy of tropical resting eggs, testing the effects of drying and refrigerating before incubation. We found that different preincubation conditions affect the hatching rate and the time to hatching in two cladoceran species in different ways. For $M$. micrura, dried and refrigerated eggs resulted in lower hatching rates, but shorter times for hatching were observed for the later. Refrigeration had no effect on $D$. birgei hatching rates and time to hatching, but drying resulted into no hatchlings.

Hatching rates in cladocerans usually vary widely. For example, hatching rates in different Daphnia magna clones ranged from 0 to $82 \%$ in an earlier study (Demeester and Dejager, 1993b). The observed patterns in hatching rates and time to hatching in our study might arise because the pre-incubation procedures are not environmentally realistic for the cladocerans from Carapebus lagoon. Sediments are never dried and low temperatures $\left(-4^{\circ} \mathrm{C}\right)$ are never experienced by the resting eggs. Thus, organisms might not be adapted to react to such environmental cues and might even be negatively affected.

To our knowledge, only one previous study tested the effects of pre-incubation procedures on the hatching of tropical resting eggs (Chittapun et al., 2005). Using resting eggs from rotifer communities collected in naturally dried sediments in Thailand, Chittapun et al. (2005) compared the effects of keeping resting eggs in 1) dark and cold $\left(24^{\circ} \mathrm{C}\right)$; 2) dark and room temperature $\left(27-42^{\circ} \mathrm{C}\right)$; and 3 ) light and room temperature conditions for different periods of time. Those authors found that the first combination of conditions provided the higher number of species and of hatchlings. In other studies from tropical regions, however, resting eggs were incubated under much colder conditions (Maia-
Barbosa et al., 2003; Pallazo et al., 2008a), which might have different effects from those observed in rotifers from Thailand.

Only the study of Maia-Barbosa et al. (2003) provides hatching rates of tropical rotifers and cladocerans, making possible direct comparisons to our results. These authors refrigerated the resting eggs before allowing them to hatch, and observed hatching rates of $60-80 \%$ for rotifers and $<10 \%$ for Daphnia laevis. It is possible that the lower hatching rate of Daphnia was caused by the exposure to "never-experienced" low temperatures, similar to our findings for $M$. micrura.

Several studies have showed that hatching cues may differ among and even within species (De Meester and De Jager, 1993b; Vandekerkhove et al., 2005a). Our results indicate that two different species ( $M$. micrura and $D$. birgei) from the same environment may react in different ways to pre-exposure to low temperatures. If different conditions are required to break dormancy among all species, then looking for a common procedure might be unfruitful. Then, studies at the community level should look for procedures that increase hatching rates of most species, whereas studies dealing with a given population could use a specific pre-incubation condition.

In conclusion, according to our results, we cannot support the idea that exposure to low temperatures $\left(-4^{\circ} \mathrm{C}\right)$ is required for breaking dormancy of resting eggs from tropical aquatic environments, although this procedure was commonly used in previous studies (Maia-Barbosa et al., 2003; Pallazo et al., 2008a,b) . Exposure to low temperatures had no effect in $D$. birgei hatching rates and reduced the hatchling numbers of $M$. micrura. Likewise we do not encourage drying resting eggs from permanent aquatic environments, in order to enhance their hatching success. We suggest that tropical resting eggs might be incubated soon after sampling the sediment or, if a period for breaking dormancy is required, they should be better kept under dark and at room temperature conditions. Maintaining the resting eggs in the dark might be required to inhibit the hatching before the start of experimental procedures.

\section{Acknowledgements}

We thank the staff of the Laboratorio de Limnologia da UFRJ and NUPEM/UFRJ for assistance during sampling and experiments. Financial support was provided by $\mathrm{CNPq}$ and Petrobras. Fellowships to JM Santangelo and LR 
Araújo were provided by CAPES. We further thank two anonymous reviewers for valuable suggestions and $\mathrm{CNPq}$ for Brazil-Italy scientific cooperation (Proc. 490954/05-7).

\section{References}

ATTAYDE, JL. and BOZELLI, RL. 1998. Environmental heterogeneity patterns and predictive models of chlorophyll a in a Brazilian coastal lagoon. Hydrobiologia, vol. 390, no. 1-3, p. 129-139.

BROCK, MA., NIELSEN, DL., SHIEL, RJ., GREEN, JD. and LANGLEY, JD. 2003. Drought and aquatic community resilience: the role of eggs and seeds in sediments of temporary wetlands. Freshwater Biology, vol. 48, no. 7, p. 1207-1218. http://dx.doi. org/10.1046/j.1365-2427.2003.01083.x

CACERES, CE. and SCHWALBACH, MS. 2001. How well do laboratory experiments explain field patterns of zooplankton emergence? Freshwater Biology, vol. 46, no. 9, p. 1179-1189. http://dx.doi. org/10.1046/j.1365-2427.2001.00737.x

CHITTAPUN, S., PHOLPUNTHIN, P. and SEGERS, H. 2005. Restoration of tropical peat swamp rotifer communities after perturbation: an experimental study of recovery of rotifers from the resting egg bank. Hydrobiologia, vol. 546, no. 281-289.

CRISPIM, MC. and WATANABE, T. 2001. What can dry reservoir sediments in a semi-arid region in Brazil tell us about cladocera? Hydrobiologia, vol. 442, no. 1-3, p. 101-105.

DE MEESTER, L. and DE JAGER, H. 1993a. Hatching of Daphnia sexual eggs. II. The effect of age and a second stimulus. Freshwater Biology, vol. 30, no. 227-233.

DE MEESTER, L. and DE JAGER, H. 1993b. Hatching of Daphnia sexual eggs .1. Intraspecific differences in the hatching responses of Daphnia magna eggs. Freshwater Biology, vol. 30, no. 2, p. 219-226. http:// dx.doi.org/10.1111/j.1365-2427.1993.tb00803.x

GARCIA-ROGER, EM., ARMENGOL, X., CARMONA, MJ. and SERRA, M. 2008. Assessing rotifer diapausing egg bank diversity and abundance in brackish temporary environments: an ex situ sediment incubation approach. Fundamental and Applied Limnology, vol. 173, no. 1, p. 79-88. http:// dx.doi.org/10.1127/1863-9135/2008/0173-0079

GOULDEN, CE. 1968. The systematics and evolution of the Moinidae. American Philosophical Association, vol. 58, no. 6, p. 1-101.

KOROVCHINSKY, NM. 1992. Sididae and Holopediidae (Crustacea: Daphniiformes): guides to the identification of the micro-invertebrates of the continental waters of the world, 3. The Hague: SPB Academic Publishing. 82 p.
MAIA-BARBOSA, PM., ESKINAZI-SANT'ANNA, EM., VALADARES, CF. and PESSOA, GCD. 2003. The resting eggs of zooplankton from a tropical, eutrophic reservoir (Pampulha Reservoir, south-east Brazil). Lakes and Reservoirs: Research and Management, vol. 8, no. 269-275.

PALLAZO, F., BONECKER, CC. and FERNANDES, APC. 2008a. Resting cladoceran eggs and their contribution to zooplankton diversity in a lagoon of the Upper Paraná River floodplain. Lakes and Reservoirs: Research and Management, vol. 13, p. 207-214.

PALLAZO, F., BONECKER, CC. and NAGAE, MY. 2008b. Zooplankton dormancy forms in two environments of the upper Paraná River floodplain (Brazil). Acta Limnologica Brasiliensia, vol. 20, no. 1, p. 55-62.

PANARELLI, EA., CASANOVA, SMC. and HENRY, R. 2008. The role of resting eggs in the recovery of zooplankton community in a marginal lake of the Paranapanema River (São Paulo, Brazil), after a long drought period. Acta Limnologica Brasiliensia, vol. 20, no. 1 , p. 73-88.

SANTANGELO, JM., BOZELLI, RL., ESTEVES, FA. and TOLLRIAN, R. 2010. Predation cues do not affect the induction and termination of diapause in small-bodied cladocerans. Freshwater Biology, vol. 55, no. 7, p. 1577-1586. http://dx.doi.org/10.1111/ j.1365-2427.2009.02389.x

SARMA, SSS., NANDINI, S. and GULATI, RD. 2005. Life history strategies of cladocerans: comparisons of tropical and temperate taxa. Hydrobiologia, vol. 542, no. 315-333.

SCHWARTZ, SS. and HEBERT, PDN. 1987. Methods for the activation of the resting eggs of Daphnia. Freshwater Biology, vol. 17, no. 2, p. 373-379. http:// dx.doi.org/10.1111/j.1365-2427.1987.tb01057.x

STROSS, RG. 1987. Photoperiodism and phased growth in Daphnia populations: coactions in perspective. In: PETERS, RH. and DE BERNARDI, R., eds. Daphnia Pallanza: Memorie dell'istituto Italiano di Idrobiologia. Istituto Italiano di Idrobiologia. p. 413-437.

VANDEKERKHOVE, J., DECLERCK, S., BRENDONCK, L., CONDE-PORCUNA, JM., JEPPESEN, E. and DE MEESTER, L. 2005 a. Hatching of cladoceran resting eggs: temperature and photoperiod. Freshwater Biology, vol. 50, no. 1, p. 96-104. http://dx.doi.org/10.1111/j.13652427.2004.01312.x

VANDEKERKHOVE, J., DECLERCK, S., BRENDONCK, L., CONDE-PORCUNA, JM., JEPPESEN, E., JOHANSSON, LS. and DE MEESTER, L. 2005b. Uncovering hidden species: hatching diapausing eggs for the analysis 
of cladoceran species richness. Limnology and Oceanography: Methods, vol. 3, no. 399-407.

VANDEKERKHOVE, J., NIESSEN, B., DECLERCK,

S., JEPPESEN, E., PORCUNA, JMC., BRENDONCK, L. and DE MEESTER, L. 2004.
Hatching rate and hatching success with and without isolation of zooplankton resting stages. Hydrobiologia, vol. 526, no. 1, p. 235-241. http:// dx.doi.org/10.1023/B:HYDR.0000041598.68424. fc

Received: 31 October 2010 Accepted: 03 August 2011 